\title{
Boudinage arrangement tracking of hydrothermal veins in the shear zone: example from the argentiferous Strieborna vein (Western Carpathians)
}

\author{
Stanislav JACKO ${ }^{1 *}$, Roman FARKAŠOVSKÝ1, Julián KONDELA1', Tomáš MIKUŠ², Barbora \\ ŠČERBÁKOVÁ', Diana DIRNEROVÁ'
}

${ }^{1}$ Technical University of Košice, Institute of Geosciences, Letná 9, 04001 Košice, Slovakia; stano.jacko@tuke.sk

${ }^{2}$ Slovak Academy of Sciences, Earth Science Institute, Dumbierska 1, 97401 Banská Bystrica, Slovakia

${ }^{*}$ Corresponding author

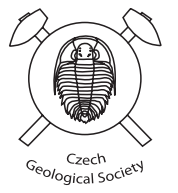

Argentiferous Strieborna vein of the Rožňava ore field occurs at the southwestern margin of the Gemeric Unit (Slovakia). The hydrothermal mineralization of the vein closely related to the Early Cretaceous tectonometamorphic shortening of the Western Carpathians. For their emplacement, the vein used the steeply dipping, fan-like cleavage and dislocation set of the Alpine regional structure. Successively the vein was integrated into the sinistral transpressional regime of the Transgemeric shear zone. A polyphase vein filling comprises Variscan metasomatic siderite remnants and the Early Cretaceous syntectonic hydrothermal mineralization, the latter consisting of two mineralization phases, quartz-siderite and quartz-sulphidic. During Cretaceous shear zone transpressional events, the vein was segmented into five individual bodies and redistributed to kinematically and geometrically different tensional and compressional boudins. The vein asymmetry increase, different vertical mineralization content and spatial distribution of mineral phases representing individual mineralization periods directly relate to a rheological contrast between the vein and surrounding rocks stress and pressure shadows distribution. The actual form and distribution of the Strieborna vein segments is the product of four boudin evolution stages: (1) pre-deformation, (2) initial, (3) boudin-forming and (4) boudin-differentiation stage that controlled vertical mineralization distribution. The sulphidic mineralization is dominated by two generations of argentiferous tetrahedrite and two youngest sulphosalts associations enriched by $\mathrm{Sb}$ and $\mathrm{Bi}$. The youngest sulphosalts of the stibnite phase at the Strieborna vein resemble contemporaneous mineral associations at the nearby Čučma stibnite vein lode. Both vein occurrences located within the Transgemeric shear zone belong to the Rožňava ore field and they are cut by the same diagonal strike-slip fault. These analogies indicate a similar genesis of terminal associations at both these vein deposits. Results of the Strieborna vein sulphosalts spatial analysis confirm their vertical zonation. The $\mathrm{Sb}$ and Ag contents decrease, while Bi contents increase, with depth and conserve boudin evolution stages created in distinct rheological environments. The vertical boudin arrangement concentrates economically most prospective parts into asymmetric boudin tension shadows.

Keywords: boudinage, transpressive shear zone, hydrothermal mineralization, rheology, deposit, Western Carpathians Received: 30 November 2018; accepted: 23 October 2019; handling editor: J. Zachariáš

\section{Introduction}

Vein-type deposits overprinted by later shearing represent infrequent type of economically mined deposits in the world. Scanty resources, structural redesigning, mineralization heterogeneity and exploration costs drifted the shearzone deposits outside of economic interest. However, some markedly sheared and boudinaged gold (Baker et al. 2002; Smith et al. 2013; Martins et al. 2016) or iron (Roache 2004; Rajabzadeh and Rasti 2017) deposits are/were profitably mined. Structural research and understanding of the shear zones in the economically potential areas may affect the mining exploration as well as increase the quality and quantity of raw materials in the heterogenic structural space.

The Rožňava ore field (ROF) comprising polymetallic Maria vein and argentiferous Strieborna vein covers a southern part of the Western Carpathian Gemeric basement (Fig. 1) and is a good example of such a mineralization type. The Strieborna vein is similar to the subparallel Maria vein, situated only $600 \mathrm{~m}$ to the $\mathrm{NW}$ and historically mined for $\mathrm{Cu}$ and $\mathrm{Sb}$. Both veins differ mainly structurally; whilst the Strieborna vein is segmented into boudins (Fig. 2a), the Maria vein is a relatively continuous unsegmented body. Basement suites of this area are penetrated by subparallel hydrothermal siderite-quartz veins generally of the NE-SW trend. Their terminal evolution related to the Transgemeric shear zone (TGSZ) activity having the same direction and amplitude of several $\mathrm{km}$.

Strieborna vein represents significant and recently one of the most valuable ROF vein ore bodies situated at the TGSZ. The vein occurs within two rheologically 
different Early Paleozoic rock sequences controlled by a competence contrast, i.e. in between brittle-deformed meta-pyroclastics underlying the vein, and ductiledeformed phyllites forming the vein's hanging wall (Fig. 2). The Strieborna vein shows a record of multiple epigenetic hydrothermal processes (Sasvári and Mat'o 1998; Hurai et al. 2002). The oldest one, consisting of nearly monomineral siderite infilling (medium- to coarse-grained siderite), dominates over the succeeding quartz-sulphidic phase. The first period of the quartzsulphidic phase comprises Ag-tetrahedrite, chalcopyrite, pyrite, arsenopyrite and first sulphosalts association of the tintinaite-kobellite series, Bi-jamesonite-bournonite, and tetrahedrite (from the oldest to the youngest phase). The second period contains younger sulphosalt association represented by chalcostibite-berthierite-garavellite series that unambiguously post-dated the Ag-tetrahedrite. Bi-stibnite, Sb-bismuthinite, and native Bi-stibnite precipitated only at the closure of this second period of the quartz-sulphidic mineralization phase (e.g., Varček 1963, 1973; Jeleň in Mesarčík et al. 1991; Grecula et al. 1995; Sasvári and Mat'o 1998; Mikuš et al. 2018 and references therein).

This study focuses on the variable boudinage development of the Strieborna vein in rheologically contrasting parental rocks. It aims to identify development of boudin structures based on the analysis of their geometry and the structural patterns of the boudin bodies. Moreover, it also constrains temporal and spatial evolution of ore phases throughout the process of vein boudinage deformation.

\section{Geological setting}

The Rožňava ore field is located in the Gemeric belt (the Gemeric Superunit of Plašienka 1999; Bezák et al. 2009) of the Western Carpathians. The southwardly adjoined basement represents an Early-Late Paleozoic megastructure of the Alpine-Carpathian chain. With respect to the paleogeography and present tectonic position, it is the southernmost unit of the Western Carpathians (Andrusov 1968) formed at the southern edge of the Variscan Orogen. The basement of the Gemeric belt, derived from the Meliatic suture zone (i.e., a rem-

Fig. 1a - Location of the study area in the Western Carpathians. b-c - The Gemeric belt (also called the Slovak Ore Mountains) bounded and segmented by several shear zones modifying (namely at the Transgemeric shear zone section) the internal structures. Associated hydrothermal vein systems concentrate along the shear zone. The Strieborna vein is located near the Rožňava town (marked by the red frame). 


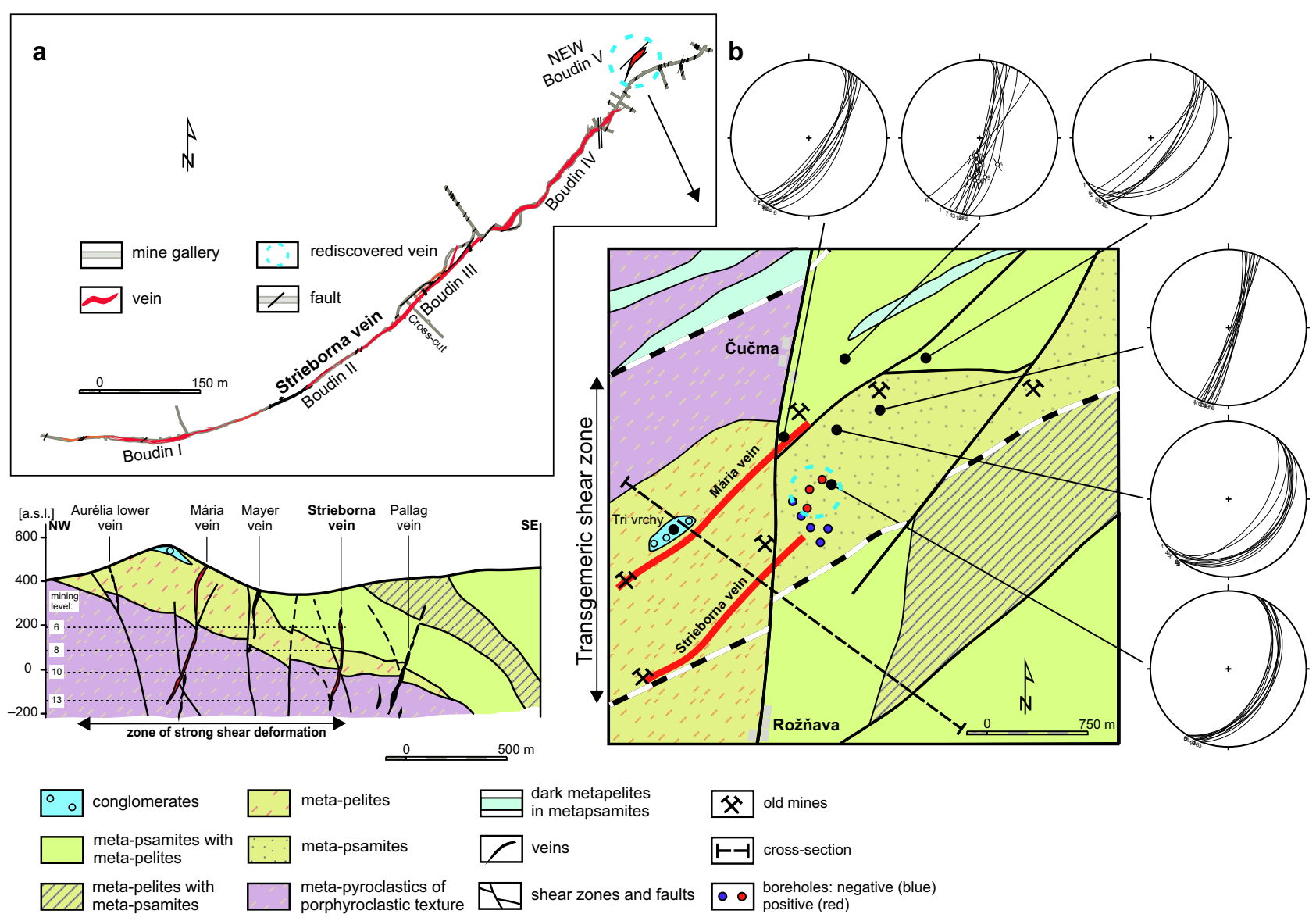

Fig. 2a - Map of the Strieborna vein at the $10^{\text {th }}$ mining level. b - Geology of the study area (after Grecula et al. 2011) exemplifying link of the ore veins to lithological boundaries and assumed TGSZ/cleavage directions. Similar relations show sharp ore veins and faults inclinations. Note common country rocks and setting of the Strieborna and Mária veins, as well as the nearby Čučma Sb vein, located at the same, steeply dipping N-S fault transecting the TGSZ course. The NW-SE cross-section reflects an influence of rock lithology vertical distribution to veins lateral and vertical morphology in the shear zone.

nant of the Meliatic Ocean trough), comprises four steeply southward dipping tectonic units. These are, from north to south, the Rakovec, Klatov, Štós, and Gelnica units - several authors also use the term "groups". They consist of Early Paleozoic to Late Carboniferous lowgrade metasedimentary and metavolcanic rocks (Bajaník et al. 1983; Vozárová et al. 2016). Only the pre-Visean gneissic-amphibolitic Klatov Unit sheet forms an exception. Intrusive Permian/Triassic bodies of the Gemeric belt - only cropping out in the Gelnica Group - occupy the southernmost part of the belt belonging to the specialized S-type granites enriched mainly of B and F volatiles (Finger and Broska 1999; Poller et al. 2002). Structurally, the Gemeric belt consists of southward-dipping nappe sheets that evolved initially from Variscan fold structures (Rozložník 1976; Grecula et al. 1995). Broadly preserved cleavage sets transposing primary foliation of the basement rocks belong partly to Variscan structural remnants (Grecula et al. 1995; Faryad 1995; Lexa et al. 2003), or to the Alpine shortening results (Maluski et al. 1993; Dallmeyer et al. 1994) as they occur in both Late Paleo- zoic and Mesozoic cover formations (Jacko and Sasvári 1990; Plašienka 1999; Németh 2002). Also, regionally significant shear zones of NE-SW and NW-SE directions cutting either basement or Mesozoic formations belong to the Alpine origin.

Early Paleozoic volcano-sedimentary, low-grade Gelnica Group itself is divided into three (Vlachovo, Bystrý potok, Drnava) formations (Bajaník et al. 1983; Vozárová and Ivanička 1996). Only the last of them is present in the ROF area. During Variscan and Alpine regional metamorphism, the Gelnica Group sequence was metamorphosed under lower greenschist conditions to variously coloured phyllites, metasandstones/metagreywackes, crystalline limestones and metavolcanic rocks only (Faryad 1991, 1995; Vozárová 1993).

\section{Methodology}

The structural analysis of the Strieborna vein was realized at the surface as well as in the underground. Authentic 
information about the adjoining, parallel and, most likely, genetically connected Mária vein (Mesarčík 1994; Grecula et al. 1995, 2011; Sasvári and Mato 1998) was also taken into consideration. In order to decipher the structural evolution, the cross-sections of both mentioned lodes have been correlated, namely at well-explored $13^{\text {th }}$ (170 m b.s.l.), $10^{\text {th }}(20 \mathrm{~m}$ b.s.l. $), 9^{\text {th }}(30 \mathrm{~m}$ a.s.l. $), 8^{\text {th }}(80 \mathrm{~m}$ a.s.1.) and $6^{\text {th }}(180 \mathrm{~m}$ a.s.l.) mining levels (Fig. 2). The Strieborna vein itself was systematically surveyed at five underground mining levels (i.e. at $13^{\text {th }}, 10^{\text {th }}$ to $8^{\text {th }}$ ). Geological structures were also correlated with controlling audio-frequency magnetotelluric source at higher spectral bands $(\sim 1 \mathrm{~Hz}$ to $80 \mathrm{kHz})$ signal.

Boudins geometrical classification is based on Ramsay and Huber (1987), Hanmer and Passchier (1991), Goscombe and Passchier (2003), Goscombe et al. (2004), Rodrigues et al. (2016) and extended by parameters described by Samanta et al. (2017). The structural reinterpretation of the vein evolution at the $6^{\text {th }}$ mining level, analysis of inter-boudin zones to boudins bulk deformations were based on Passchier and Druguet (2002), Dabrowski and Grasemann (2014) and post-boudinage plastic deformations due to strain softening according to Lloyd and Ferguson (1981), Ghosh and Sengupta (1999), Passchier and Trouw (2005), Rodrigues and Pamplona (2018). We compare surface structural data with the ore vein mineralization distribution and structural pattern of the Strieborna vein ore body. The vein was additionally surveyed at two ( $6^{\text {th }}$ and $\left.10^{\text {th }}\right)$ sublevels, two raises, 13 underground and one surface drill hole.

\section{Results}

\subsection{Structure and lithology}

The Drnava Fm. rock sequences (Fig. 2) show NE-SW direction and generally moderate SE inclination of the structural planes. They were deformed by the Transgemeric shear zone (TGSZ) of the same direction in the studied area. The Rožňava ore field rock suites, including mineralized veins, were incorporated into the TGSZ structural pattern. Ore veins of the studied area were developed within metapsammitic rocks of the Drnava Fm. that are irregularly intercalated by dark metapelites with tiny conglomeratic and carbonate layers (Fig. 3). All mentioned rocks were metamorphosed at greenschistfacies conditions (Faryad 1991, 1995; Vozárová 1993). The Strieborna vein is best developed in the rheologically competent metavolcanic and metapsammitic rocks (Fig. 3). If hosted by phyllites, the vein course and thickness reduce substantially.

Metavolcanic rocks are foliated, originally aphanitic pyroclastics of rhyolite composition, formed mainly by quartz and white mica. Sporadic small-scale compositional layering (up to $1 \mathrm{~m}$ thick) or banding is typical of these rocks. The younger association, rimming mainly exocontact of the Strieborna vein, consists of newly formed hydrothermal minerals comprising quartz, siderite, pyrite, and pyrrhotite. At the vein's footwall occur also porphyric rocks. They contain quartz and, rarely, feldspar porphyroclasts reaching on average up to $5-10 \mathrm{~mm}$ in size. From the base to the top, metavolcanic rocks pass through the metapsammitic rocks up to phyllites (Fig. 2). The contact between these three rock types is of discrete character.

Metapsammites of the studied area belong to two lithological groups, quartz arenites/ graywackes and lithic arenites/lithic wackes. The most common are the lithic metagreywackes. Re-

Fig. 3 Core samples from the exploration borehole drilled in the study area. a - Brittle-ductile deformation of fine- to medium-grained light grey metagraywacke interbedded with the dark grey phyllite. $\mathbf{b}$ - Prolonged lenses of light grey metagreywackes alternating with dark grey phyllites. $\mathbf{c}-$ Brittle deformation of siderite $(\mathrm{Sd})$ veins in the metagraywacke medium. Some brittle fractures are filled by pyrrhotite (Po). d - Boudinaged siderite vein. Surrounding vein fractures are filled by pyrrhotite. 


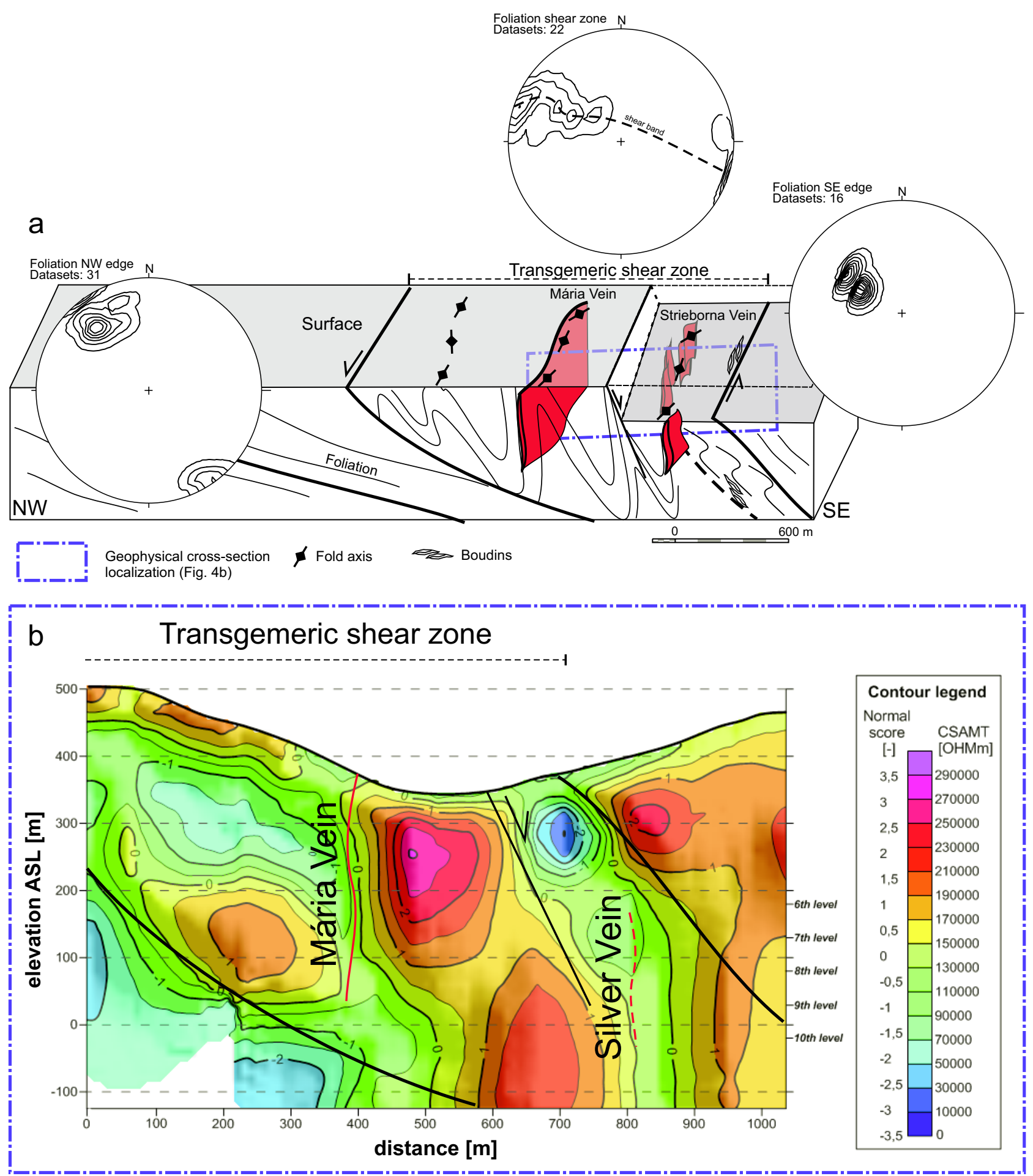

Fig. 4a Structural position of the Strieborna and Mária veins in the Transgemeric shear zone and foliation course distribution in the neighbouring rock segments. Contour diagrams from different parts of Transgemeric shear zones confirm shear band flexure in the middle segment of the studied area. b-Geophysical interpretation of auditing audio-frequency magnetotellurics source (CSAMT) supports similar anomalies at the mined (Mária) and surveyed (Strieborna vein) parts and inclined geological structure of transversal NW-SE cross-section.

garding granularity, they could be interpreted as poorly sorted, medium- to coarse-grained metapsammites. The dominant constituent of these rocks is quartz, where the relationship between prevailing grain size and the grain roundness is evident. The fine-grained rocks show a better sorted clastic material and more rounded quartz grains than the coarse-grained metapsammites. Lithic fragments and feldspar clasts reach also a substantial amount. 

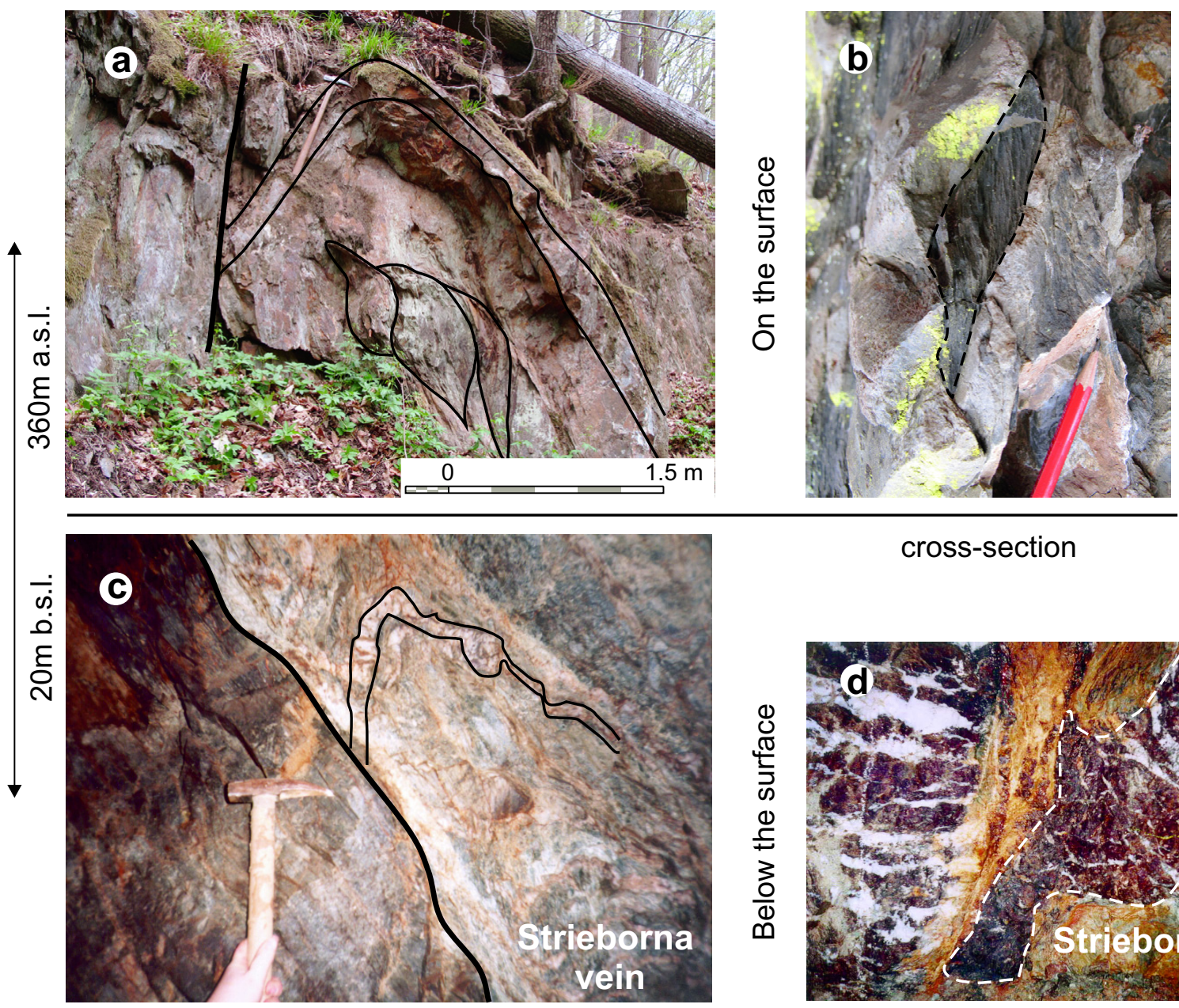

cross-section

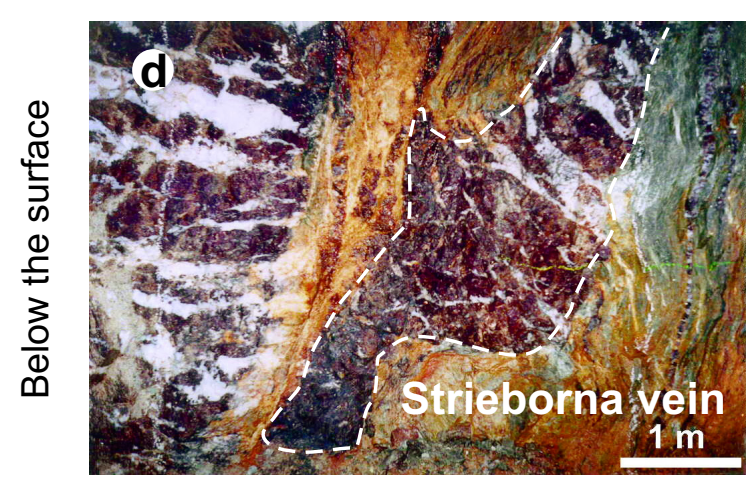

Fig. 5 Comparison of structural patterns (elevation $400 \mathrm{~m}$ ) between surface and underground. $\mathbf{a}$ and $\mathbf{c}-$ Limb amputation of fault-related folds parallel with Transgemeric shear zone. b and $\mathbf{d}$-Compressive asymmetric boudin bodies developed across the vertical profile of the shear zone. Note the quartz ladder filling the boudinaged quartz-siderite veinstone.

Grey to black phyllites form up to $10 \mathrm{~m}$ thick layers in the metapsammitic rocks. In detail, they exhibit banded structure due to the rhythmic alternation of light-grey and dark-grey bands. The dark colour is associated with high organic carbon content. The rocks are composed mainly of white mica and quartz, chlorite is subordinate.

\subsection{Cleavage and folds}

A typical feature of the Gelnica Group rocks is a steep cleavage set that relates to area shortening. Early Cretaceous tectonometamorphic processes (deformation stage AD1 sensu Németh et al. 1997) formed an asymmetric positive fan structure across the entire length of the Gemer belt (Lexa et al. 2003). Intensively sheared rocks of the Rožňava ore field show changes in the cleavage orientation; analogically the Strieborna vein changes its strike from the SW to the NE. It means that the Strieborna vein is a curved structure in the studied area, which was proven by many structural measurements and by the position of the positive boreholes (Fig. 2b). In the studied area, the SW-NE orientation of the cleavage strike lines in the south changes to the SSW-NNE and, finally, SW-NE direction in the north (Fig. 2b). In the transversal vertical cross-section, the originally moderate cleavage inclination gradually steepens (Figs 2 and 4). The south-eastern edge of the area is characterized by open shear folds and steeply dipping NE-SW directed cleavage. A progressive structural evolution, caused by shear strain, successively transposed Alpine folds into a position parallel to the curved structure of the Gemeric belt. Consequently, fold axes orientation varies between SW-NE and SSW-NNE, depending on their position in the above-mentioned bent structure. Typical are close folds with similar 2 fold shapes (Ramsay and Huber 1987). They usually have one limb cut as a result of transpressive shear movements (Fig. 5). An average fold amplitude at the shear zone varies from 0.5 to 2.0 meters (Fig. 5). The axial plane cleavage shows NE-SW strike lines orientation and, in general, SE inclination. The stretching lineation on the 


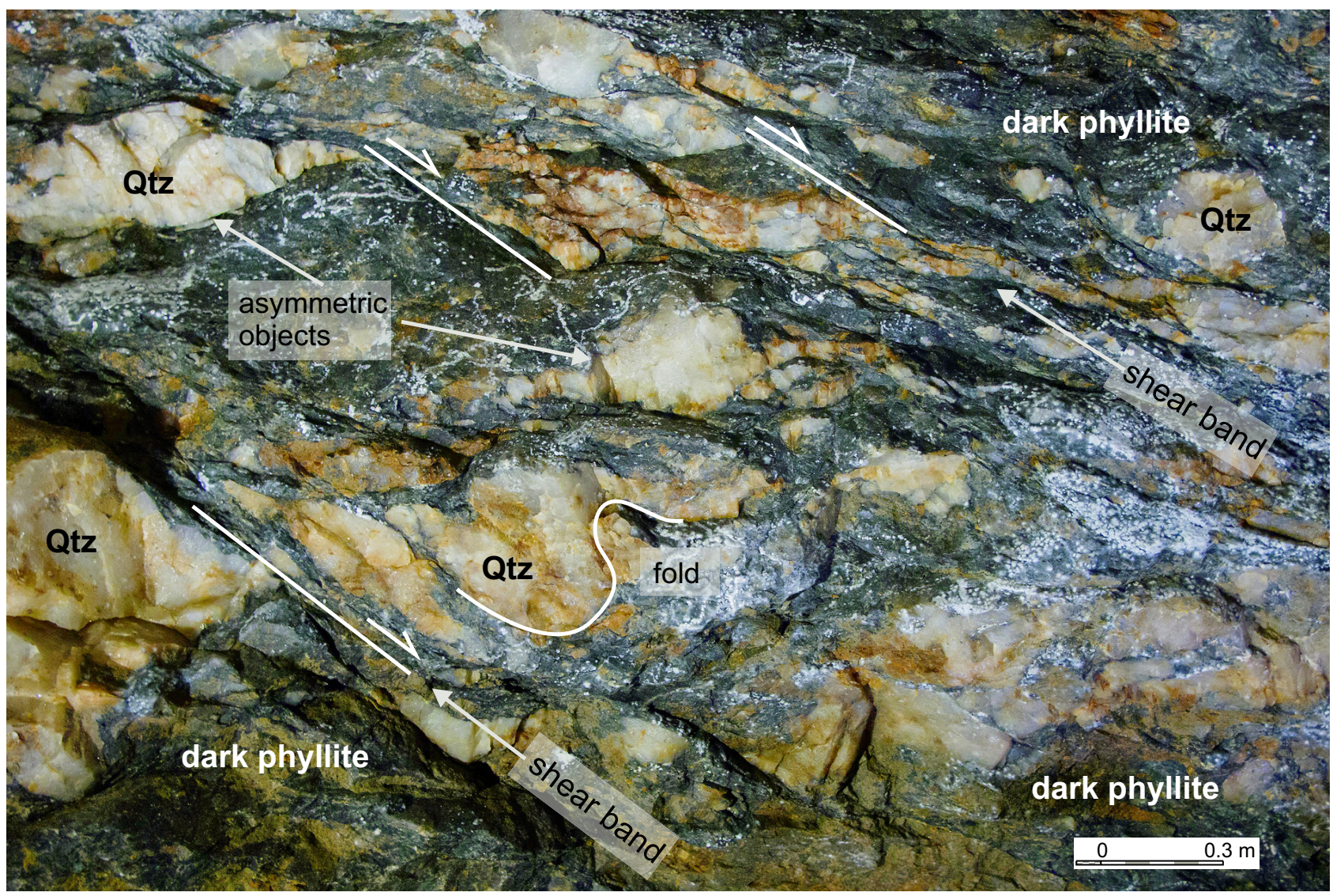

Fig. 6 Tightly folded dark phyllites interbedded with hydrothermal quartz layers, deformed by the strike-slip shearing parallel to NE-SW Transgemeric shear zone course, the roof of the $6^{\text {th }}$ mining level. Strike-slip deformation is visible in shearing of folded pre-quartz-siderite hydrothermal quartz veins. Quartz layers shear bands show monoclinic fabric symmetry and sharp-tips oriented to TGSZ shear zone direction.

cleavage planes dips moderately towards the S to SSW. The fold axial cleavage planes are frequently injected by hydrothermal quartz veins. They are well-identified in the adjacent fold limbs, mainly at rheological boundaries between slates and hydrothermal quartz filling.

\subsection{Boudinage}

Nicely preserved Strieborna vein boudins occupy a depth interval between $6^{\text {th }}$ and $10^{\text {th }}$ mining levels, forming five boudin bodies here (Fig. 2a). Their length varies from several tens to more than $100 \mathrm{~m}$. They originated along two dislocation sets filled by mylonites of $\mathrm{m}-\mathrm{dm}$ thickness. The more frequent set of the NNE-SSW direction with subhorizontal striations is passing parallel to the Rožňava-Čučma village fault. The second set of subvertical fault planes shows NE-SW orientation (Figs 2 and 4), and inclination to SE. Structural data indicate that the process of the Strieborna vein boudinage closely related to the strike-slip activity of the mentioned fault sets. The Strieborna vein and the Čučma stibnite vein recline at the same NNE-SSW fault structure and they contain the same mineral associations of the quartz-sulphidic phase
(Grecula et al. 1995; Sasvári and Mato 1998; Mikuš et al. 2018). They probably underwent a similar hydrothermal evolution during the final steps of vein formation.

The brittle-ductile mylonitic shear zone up to $1 \mathrm{~m}$ thick runs near the Strieborna vein at $6^{\text {th }}$ mining level, parallel to foliation in the metapelitic rocks. The dark phyllites enclose lenses of white hydrothermal quartz with variable lengths and visible signs of shear deformation. They are segmented by shear bands, or they form boudins, asymmetric objects, and remnants of isoclinal folds (Fig. 6). The minor veins, several $\mathrm{cm}-\mathrm{dm}$ thick and segmented most often to boudins, occur close to the main vein body (Fig. 7). They are parallel to the cleavage of surrounding metapelites as well as parallel to the Strieborna vein and they are formed by siderite and quartz. The minor veins can be also deformed by shear bands or folded (Figs 6-7).

Based on the kinematics (sensu Goscombe et al. 2004), the minor boudins can be divided into two types: those that are segmented by shear movements (Fig. 7) and those, the origin of which relates to tension deformation (Fig. 9a). According to the boudin geometry, they can be divided into three main categories. Asymmetric shear band boudins have boudin blocks separated by shear planes (Figs 5, 7). 

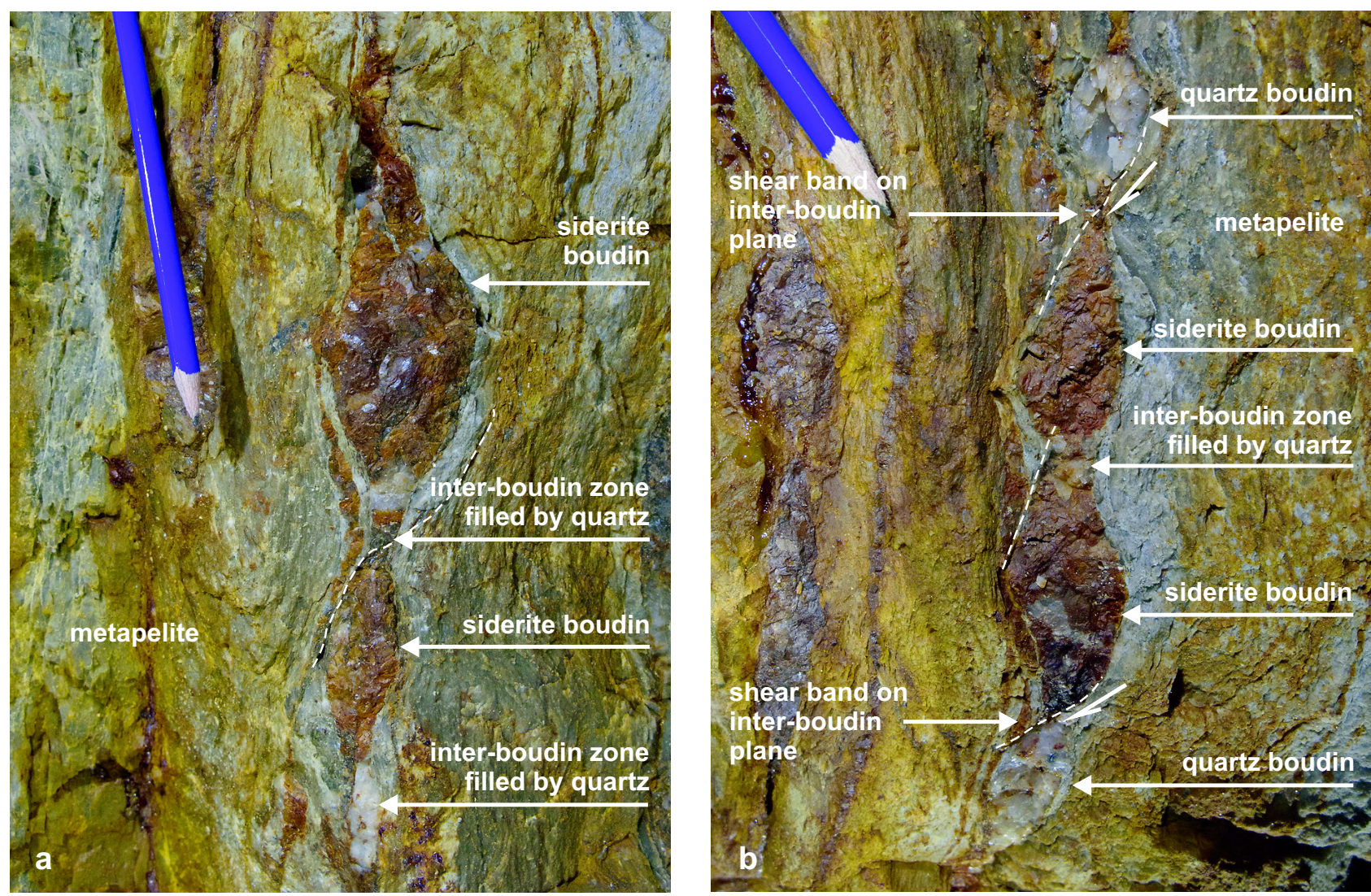

Fig. 7 Asymmetric shear bands at inter-boudin plane filled by brown siderite and light quartz. a - Strongly compressed homogeneous siderite boudins delimited by straight shear planes with conical quartz tails formation. $\mathbf{b}$ - Lens-like distribution of sideritic and quartzose boudins, divided by shear band inter-boudin planes resulting from shear deformation of relatively much more thickened ductile phyllite surrounding.

The boudin blocks are formed mainly by siderite, less by quartz (Fig. 7a-b). The inter-boudin zone is filled by quartz or by surrounding metapelitic rock. In some cases, the terminal parts of the shear band boudin blocks were dragged

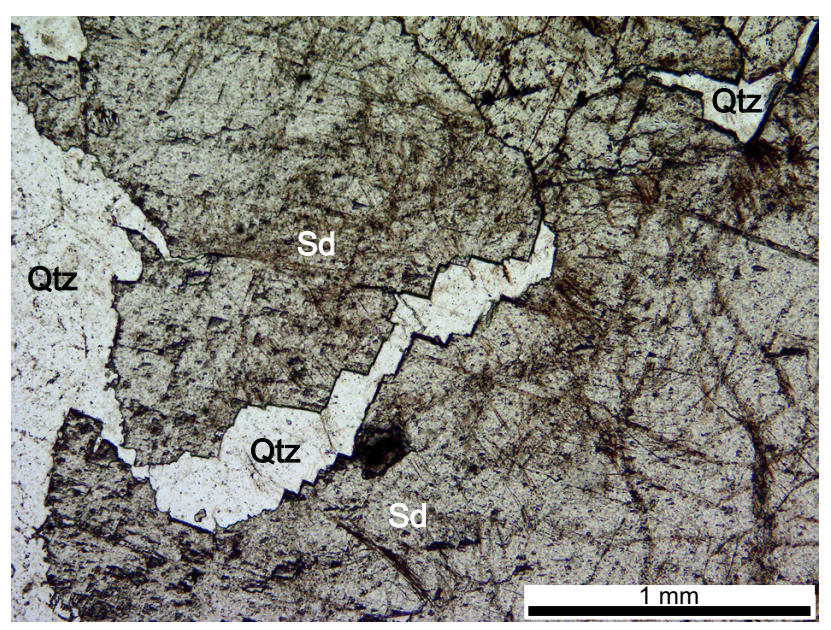

Fig. 8 Microscopic view of sharp siderite boudin margin and interboudin quartz filling. Siderite (Sd) limited via straight planes shows distinct deformation cleavage. Younger, post-deformation quartz (Qtz) injection replaced siderite open fracture conformably to rhombohedral siderite cleavage planes. in the direction of the boudin separation and form drawn boudins. The boudin blocks of the symmetric torn boudins are formed always by siderite and inter-boudin zones are filled by quartz (Fig. 9). The siderite in the boudin blocks is brittle deformed. Single grains are separated from each other or they are fractured along their cleavage planes. The open space among the separated parts of the siderite grains is filled by quartz (Figs 8,9a-b). Various microstructural markers were observed in torn boudins, previously unknown from the ROF area (Fig. 9b-c). Pressure markers like tapered stylolite teeth (Fig. 9c) and stylolitic joint surfaces indicate maximal compressive stress oriented perpendicularly to the foliation. The minor siderite veins deformed as a brittle material set in the more ductile metapelites. The foliation planes of the surrounding metapelites are bent around the boudin structures (Figs 7a-b, 9a).

\section{Discussion}

\subsection{Structural coherence}

The structure of the Gemeric belt reflects the impact of several Variscan and Alpine deformation events 

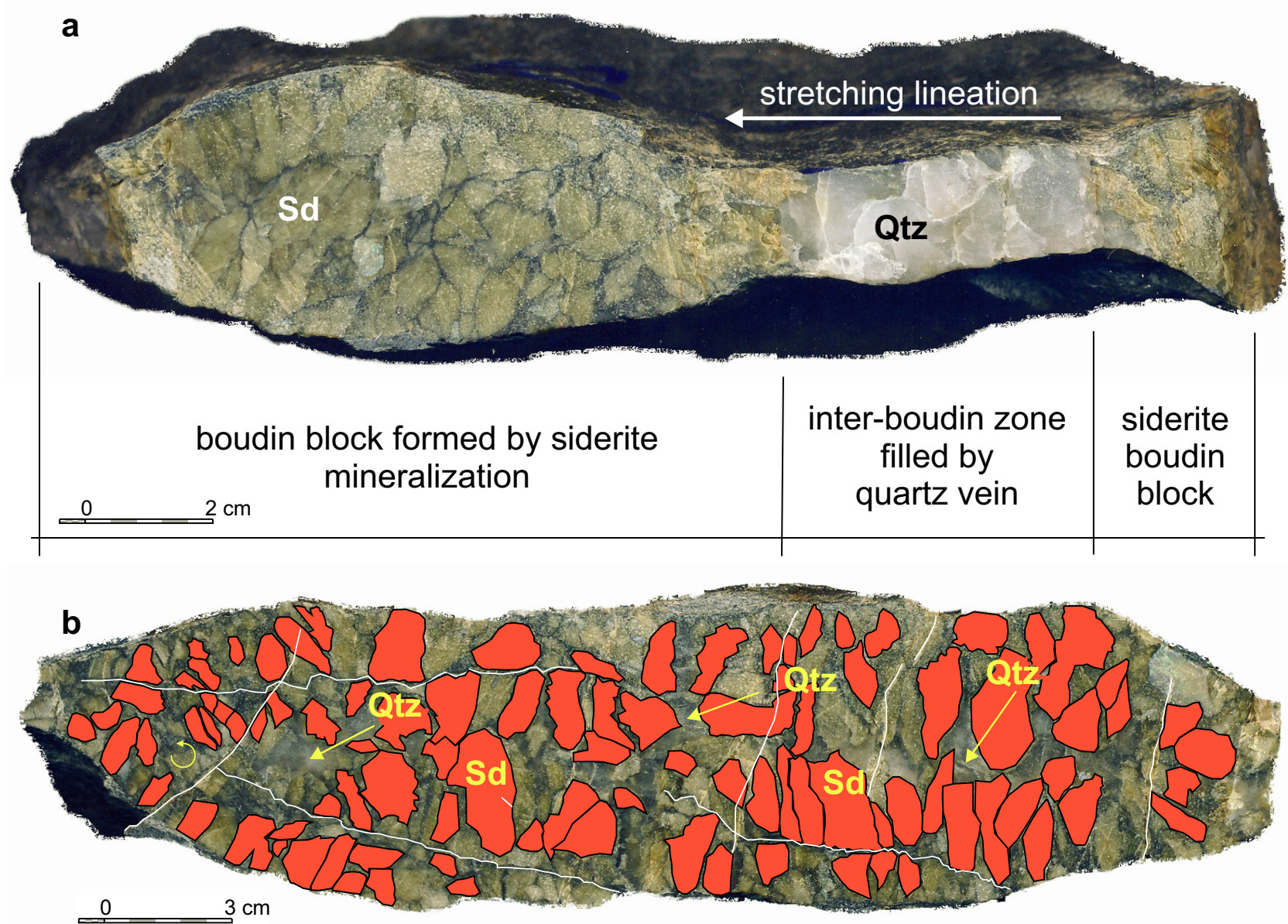

\section{boudin block formed by fractured siderite, fractures are filled by quartz}

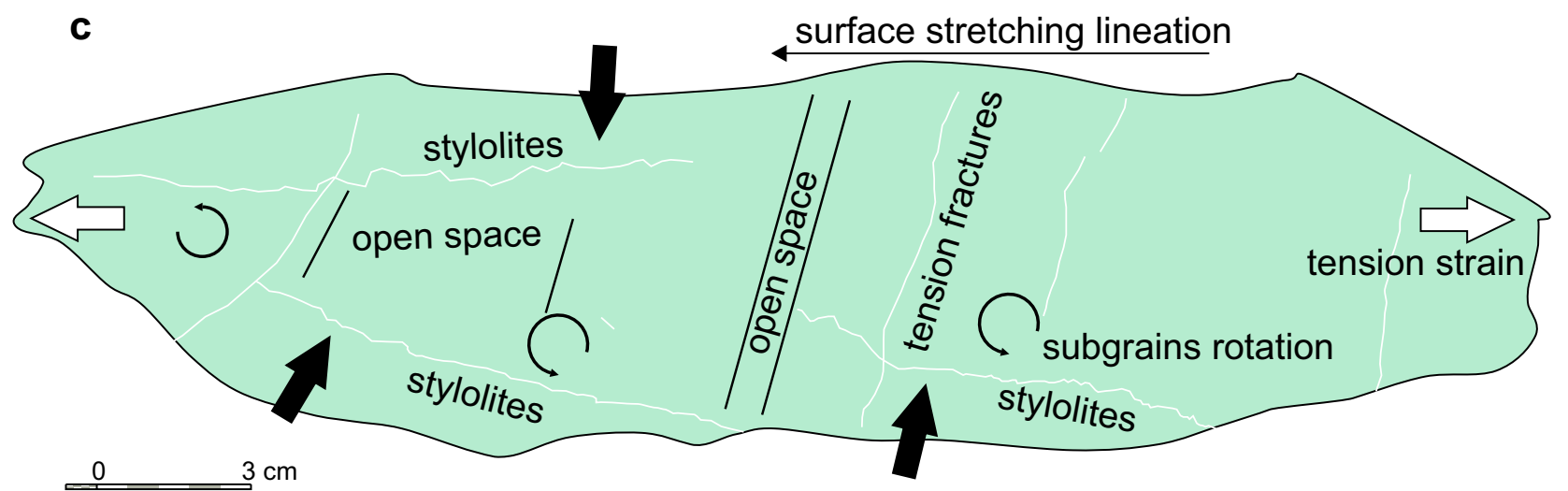

Fig. 9a - Symmetric torn boudins filled by siderite and younger quartz mineralization. $\mathbf{b}$ - Cleavage planes and siderite tensile fractures filled by younger hydrothermal quartz. c - Tensile boudin internal structure composed of several structural elements, i.e. responded paleostress marked by stylolites and tension fractures. Boudinal stretching also allowed subgrains rotation into paleostress-free boudin segments.

(Rozložník 1976, 1980; Mahel' 1986; Faryad 1991; Plašienka et al. 1997; Grecula et al. 1990, 2011 and references therein). The Variscan pervasive fold structure of the superunit, accompanied by greenschist-facies metamorphism, and following nappe formation, have prepared the regionally penetrative planar set for the subsequent Alpine structural and metallogenetic processes. 
EARLY-MIDDLE JURASSIC

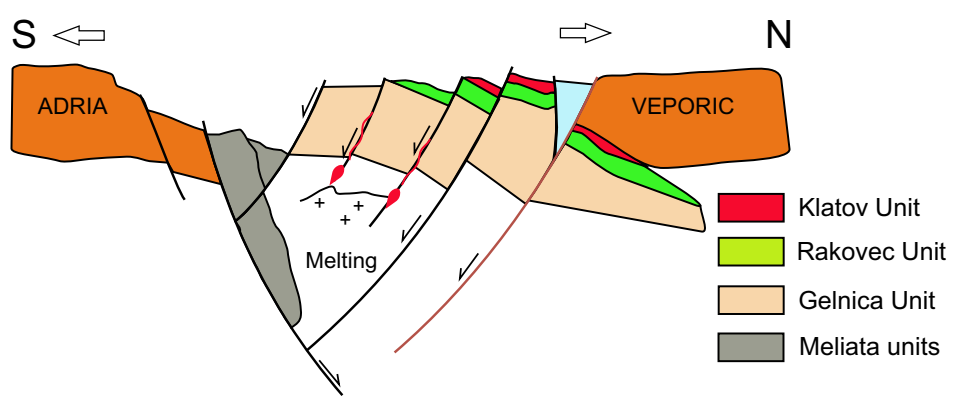

LATE JURASSIC-EARLY CRETACEOUS

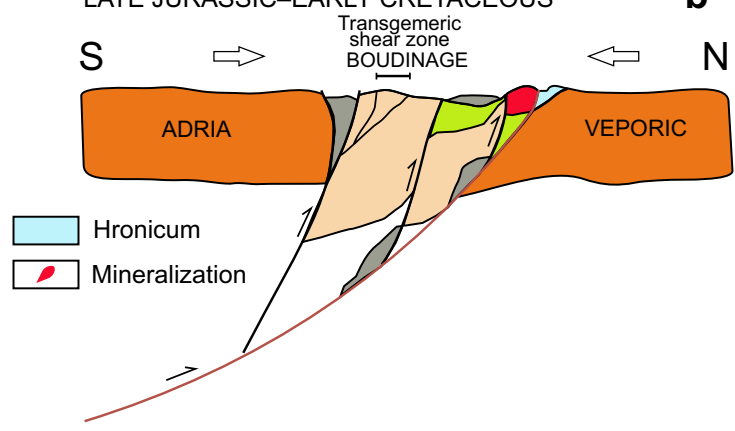

Fig. 10 Transition from divergent to convergent regime in the southern part of the Western Carpathians. a - Delamination of the Meliata Unit trough by dominant listric fault. Heavy oceanic core and deep sediments were dragged underneath the Gemeric Unit domain. Melting of underthrusted rock complexes enriched hydrothermal solutions by elements like $\mathrm{Mg}, \mathrm{Fe}, \mathrm{Sb}, \mathrm{Bi}, \mathrm{Ag}$ or $\mathrm{Au}$. b - Collision processes (AD1 tectonic phase sensu Németh et al. 1997; Lexa et al. 2007) transformed antithetic faults into north-vergent imbricate structures and initiated the Alpine shortening history of the Western Carpathians.

The Western Carpathian Alpine shortening initiation (Fig. 10) basically related to the closure of the Late Jurassic Meliata trough, and consecutive thrusting of its successions over a southern part of the Gemeric Unit at c. 160-150 Ma (see also Dallmeyer et al. 1996; Faryad and Henjes-Kunst 1997; Plašienka 1999 and references therein). Variscan structures of the Gemeric domain have been throughout the following Cretaceous events either accentuated or substantially reworked. Consequently, the origin and subsequent development remain frequently unclear.

The Early Cretaceous onset of the Western Carpathian collisional wedge formation is supported by the ${ }^{40} \mathrm{Ar}-{ }^{39} \mathrm{Ar}$ dating yielding ages of $c$. 140-100 Ma for white micas growing in penetrative foliation planes developed in buried Veporic basement complexes or in their Permo/ Triassic cover (Maluski et al. 1993; Dallmeyer et al. 1996, 2008). A terminal part of this event is also considered as minimal interval of the Gemeric Unit thrusting onto the northern Veporic block (e.g. Plašienka et al. 1997; Plašienka 1999; Schulmann et al. 2005; Putiš et al. 2009; Grecula et al. 2011). Continuing progradation of the Western Carpathian wedge (at c. 100-90 Ma) resulted in cover nappes emplacement (e.g. Plašienka et al. 1999; Putiš et al. 2009) succeeded by the pre-Turonian extensional and heterogeneous exhumation of the Veporic and Gemeric units (Putiš et al. 2009). This event caused large-scale open folding followed by the creation of steeply dipping, fan-like axial cleavage set and faults formation either in the Gemeric realm, adjacent Veporic Unit or in overthrust Hronic cover nappe pile (Jacko 1979; Reichwalder 1982; Rozložník 1984). Steeply inclined soles of the Variscan thrust sheets and fold axial fan-like cleavages/faults of the units, frequently used as metalliferous structures, have been afterward spatially incorporated into the pre-Paleogene Gemeric shear zones of the NE-SW and NW-SE direction.

The Gemeric Unit shear zones (Fig. 1b-c) reaching several $\mathrm{km}$ amplitude, consist basically of sub-parallel strike-slip faults which significantly transform and rhythmically cut off the former Variscan and Alpine structures. Deforming them at simple shear brittle-ductile conditions (Grecula et al. 1990; Sasvári and Mat'o 1998), they markedly modify an initial structural pattern including original ore vein distribution of the Gemeric Unit. Internal structures and shear zones dimensions were subsequently overprinted by several repeated Tertiary tectonic events.

The Transgemeric shear zone (TGSZ, Grecula et al. 1990) cutting the Gemeric realm axially in NE-SW direction (Fig. 1) consists of numerous steeply dipping sinistral strike-slips spreading at $2-3 \mathrm{~km}$ amplitude. The TGSZ that is $80-120 \mathrm{~km}$ long comprises numerous ore veins of the Gemeric belt including those of the Rožňava ore field (ROF, Figs 2, 4). The TGSZ structural evidence testifies both prolonged kinematic evolution of the zone and close relations to multi-phase formation of the Strieborna vein (see Grecula et al. 1995; Sasvári and Mat'o 1998; Hurai et al. 2008). Shear deformation of different magnitudes led to a multiple shearing of the rock sequences, ore veins boudinal segmentation and/or contemporaneous redistribution of the latest phases ore mineralization within the Strieborna vein (Figs 2, 5, 6). From a comparison of analogous structural evolution and similar low-grade metamorphic conditions of the Gemeric and Veporic units seems to be obvious that the Early Cretaceous (c. 75-85 Ma) interval could be regarded as onset of the TGSZ transpressional deformations (Hurai et al. 2008).

\subsection{Metallogenic problems}

Distinct remnants of metasomatic siderite bodies clearly replaced by hydrothermal quartz-siderite assemblage are known from deep mining levels of the Rožňava mine, as well as from other Gemeric veins. This suggests that at least some carbonate inlayers of the Drnava Fm. were metasomatized prior to the formation of Early Cretaceous 
vein-type mineralization in the Gemeric belt. One of the key metallogenic problems of hydrothermal mineralization in the Gemeric Unit is the source of $\mathrm{Mg}, \mathrm{Fe}$ and other metallic elements that are present in hydrothermal veins.

Grecula et al. (2011) solved this issue through percolation of fluids released from the precursor rocks (namely black schists and bimodal volcanites), either during the Variscan low-grade metamorphism or during the Alpine greenschist-facies retrograde overprint. Also, Hurai et al. (2008) reached a similar conclusion, i.e. that ore fluids parental to the Gemeric siderite veins had to be enriched in $\mathrm{Fe}$ and $\mathrm{Mg}$ through their interaction with underlying Paleozoic metabasites and volcaniclastics. Lexa et al. (2007) and Németh et al. (2016) invoked rather fluid convection due to overheating associated with Late Variscan post-collisional mantle upwelling and crustal thinning.

Rozložník (1990) reminded two essential problems regarding siderite hydrothermal mineralization in the Western Carpathians: first - it is bound to pre-Mesozoic Inner Western Carpathians units and extreme accumulation of siderite in the Gemeric belt in excessively shortened Early Paleozoic complexes, and second - a presence of an extensive "mantle metals" signature in these hydrothermal veins. He sought the source of metals in the Pieniny Klippen Belt basic/ultrabasic mantle rocks underthrusted below the entire Inner Western Carpathians units in Cretaceous times (Rozložník 1990, Fig. 5).

All the above-mentioned authors put the onset of siderite vein formation into the synorogenic Early Cretaceous interval. In the studied area, this is confined by the $124 \pm 1.7 \mathrm{Ma}$ ${ }^{40} \mathrm{Ar}-{ }^{39} \mathrm{Ar}$ age of muscovitephengite concentrate from the Maria vein quartz-tourmaline phase (Hurai et al. 2008).

We also assume an initial mobilization of metals owing to mantle assistance. However, in regard of above-mentioned, we tend to seek an initial source of metals in the Middle-Late Jurassic continental crust and Meliatic mantle mobilization, as indicated by ${ }^{40} \mathrm{Ar}-{ }^{39} \mathrm{Ar}$ data from the Meliatic Unit (150170 Ma; Maluski et al. 1993;

Fig. 11 Successive scheme of the Strieborna vein hydrothermal mineralization with prevailing deformation processes (according to Sasvári and Mato 1998; Mikuš et al. 2018).
Faryad and Henjes-Kunst 1997; Dallmeyer et al. 2008). Even the southern rim of the Gelnica Group, directly adjacent to the Meliatic Ocean eastern border, was likely underthrusted as early as at the onset of the crustal subduction (172 Ma, e.g. Faryad and Henjes-Kunst 1997). Thereafter, throughout the Early Cretaceous syntectonic period, mobilized mantle/crustal fluids infiltrated into penetratively prepared structures of the Gemeric Paleozoic rocks, precipitating siderite hydrothermal mineralization. This idea is supported by the large amount of mantle ultrabasites in Meliatic nappes overriding the Gemeric Paleozoic basement and by extensive siderite veins accumulation in the Gemeric belt basement, compared to the northern Western Carpathian basement complexes.

\subsection{Formation of the Strieborna vein quartz-sulphidic phase}

Both shearing and boudinage events separated the Strieborna vein quartz-siderite phase from the quartz-sulphidic one (Fig. 11). Ag-enriched tetrahedrite and other minerals precipitated during the first and second periods of the quartz-sulphidic phase. Diagonal tetrahedrite veinlets in siderite lodge and broad molten tetrahedrite clusters enclosing siderite fragments (Fig. 12) unambiguously document position of tetrahedrite in the mineral succession

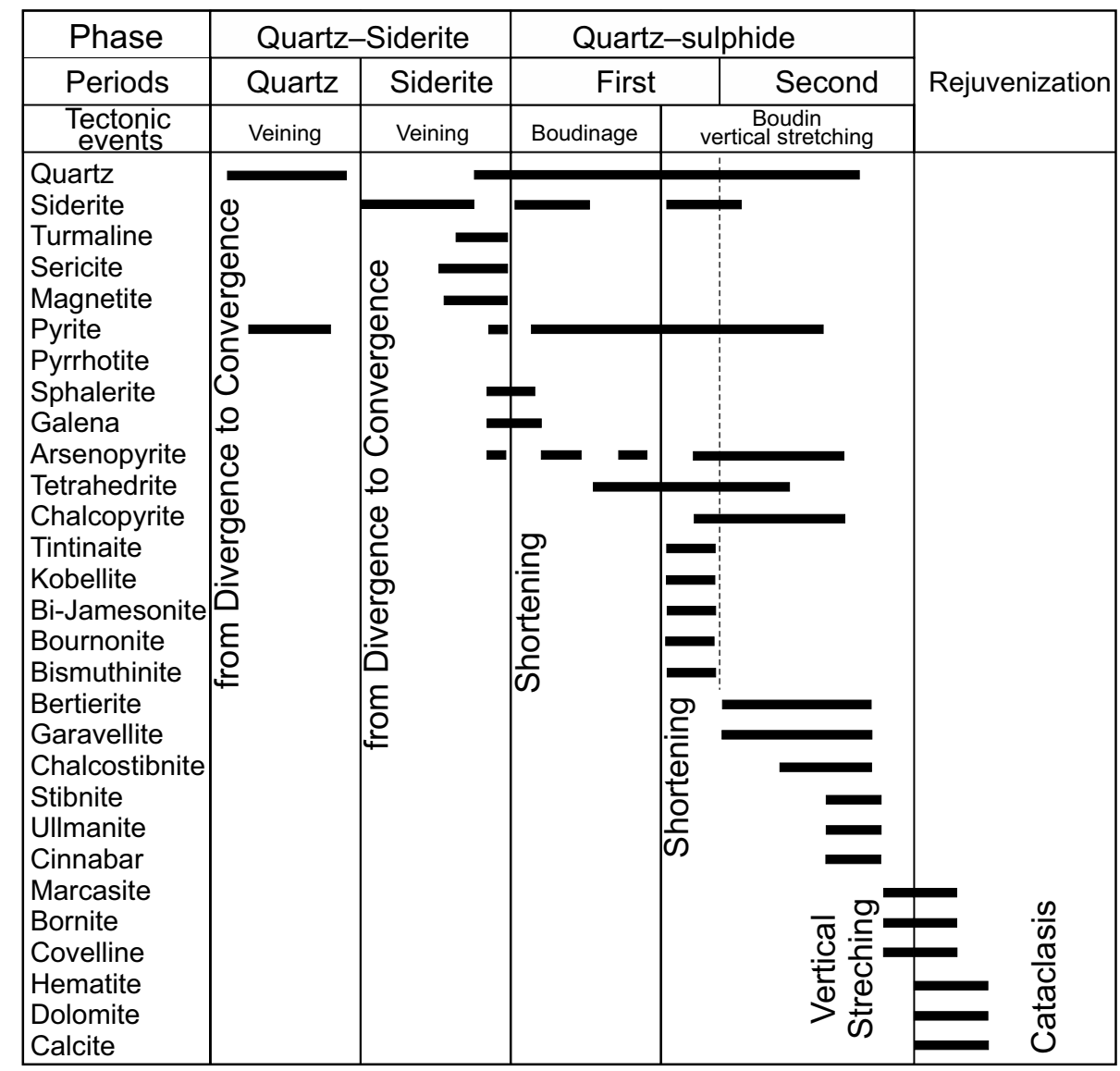




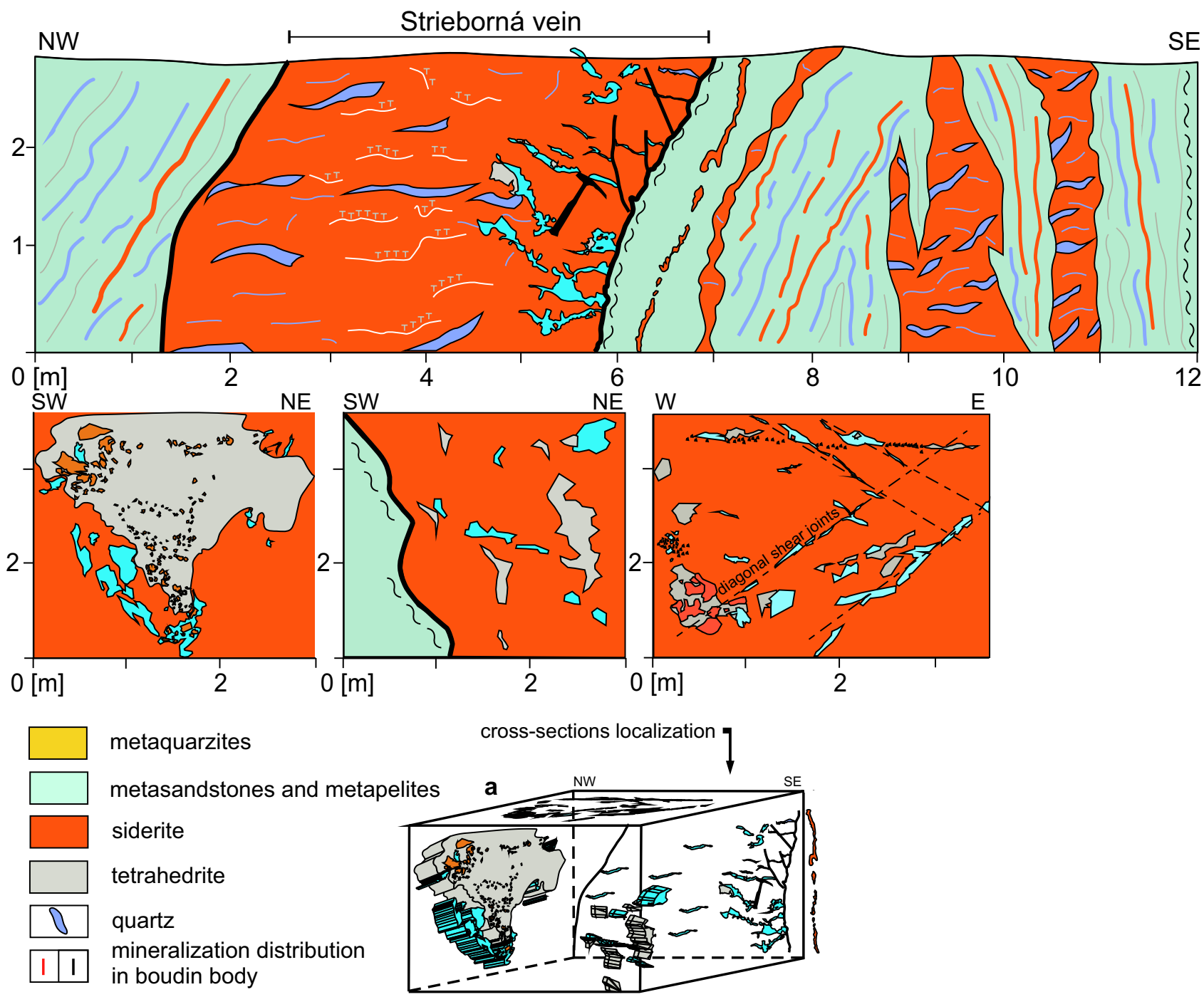

Fig. 12 Spatial view of a boudin at the $6^{\text {th }}$ mining level. Boudinage created irregular tetrahedrite bodies and was tectonically restricted by fault subparallel to Transgemeric shear zone. The spatial position of tensile diagonal shear joints and tetrahedrite accumulation relates to minimum stress direction.

(Fig. 11). Similar relationships show tetrahedrite inherence at siderite brecciated fragments, replaced by bulky nests of massive tetrahedrite (Mikuš et al. 2018, Fig. 3). Moreover, tetrahedrite/siderite contacts are etched by berthierite, garavellite and stibnite veinlets (Fig. 5). This younger sulphosalts association shows an opposite vertical zonation on mine-scale (i.e. decrease in $\mathrm{Sb}$ and an increase in Bi contents with increasing depth). In this context we are able to track volumes of argentiferous tetrahedrite. Tetrahedrite contents up to $0.71 \mathrm{wt} . \% \mathrm{Ag}$ are restricted to deeper mining levels and deeply located, bulkier symmetric boudins (Fig. 13). In vertically shifted asymmetric boudin, emplaced in the soft surrounding environment of the upper, i.e. the $6^{\text {th }}$ mine horizon, $\mathrm{Ag}$ content increases even to $0.74-1.71$ wt. $\%$. The Strieborna vein vertical ore distribution likely reflects more factors than other deposits in the Rožňava ore field, e.g. different mineralization sources, vertical precipitation differences at both periods of the second, i.e. quartz-sulphidic mineralization phase, distinct rheological contrasts of the parent rocks environment, and mineralization content/volume changes due to vein boudinage deformation events (Figs 4, 6, 9, 12-13).

As an initial source for Gemeric Unit quartz-sulphidic phase formation, Hurai et al. (2008) determined an immiscible gas-brine mixture enriched by basement rocks percolation at $c .140-300^{\circ} \mathrm{C}$. For sulphide veins of the South Gemeric zone, they assumed up to $16 \mathrm{~km}$ burial depth and onto 0.6 kbar decreased fluid pressure during crystallization. Formation of the sulphidic assemblage in the Rožñava area possibly related to younger, Late Cretaceous transpressional TGSZ events, as would certify an appropriate $\mathrm{K}-\mathrm{Ar}$ diapason (68-97 Ma) from Čučma quartz-stibnite vein and stilpnomelane from the Rožnava siderite deposit (Kantor 1957; Bagdasaryan et al. 1977). 


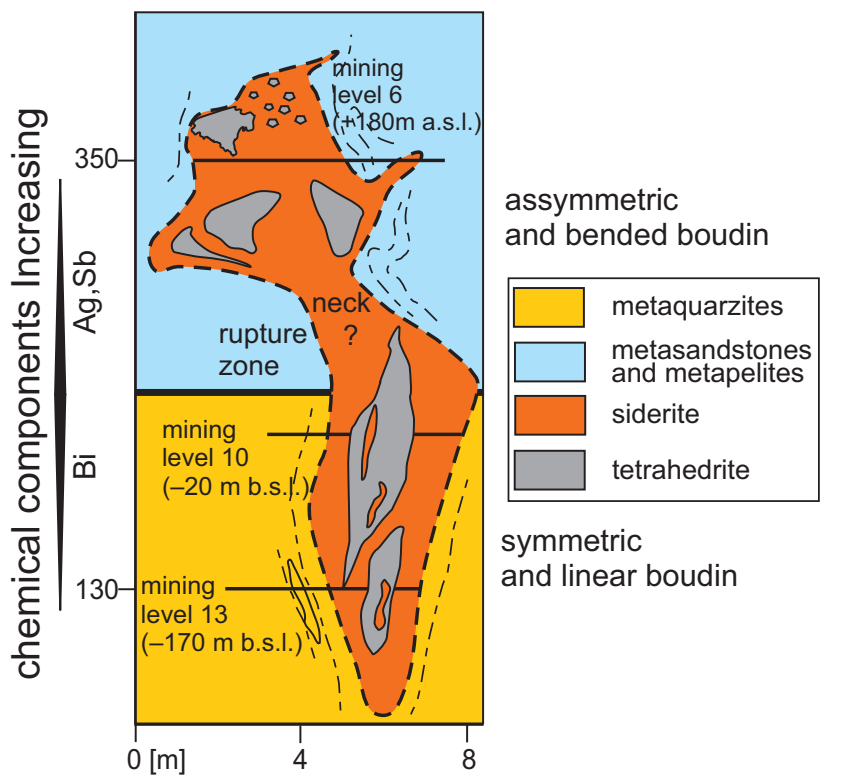

Fig. 13 Vertical scheme illustrates creation of boudins of symmetric and asymmetric morphology due to different host-rocks rheology. Distribution of chemical compositions relates to successive mineralization process of tetrahedrite and sulphosalts as well as boudin formation.

\subsection{Boudinage of the Strieborna vein}

Hydrothermal minerals constituting the Strieborna vein precipitated during the entire (long-lasting) deformation evolution (Fig. 14), comprising three deformation stages in detail (Fig. 11). The presence of an older boudinage event, pre-dating the quartz-sulphidic mineralization phase, has not been verified in the ROF area till now. This suggests onset of the Strieborna vein early boudinage somewhere at the beginning of the quartz-sulphidic mineralization phase. On the other hand, the youngest minerals of the Strieborna vein mineralization (i.e. end of the second period of the second mineralization phase) lack evidence of deformation but create veinlets and (or) myrmekitic intergrowths at tetrahedrite-siderite contacts (Mikuš et al. 2018 and Fig. 9). Hence it is reasonable to assume a Late Cretaceous post-deformation closure of the Strieborna vein hydrothermal mineralization.

\section{Conclusions}

The origin of argentiferous Strieborna vein of the Rožňava ore field located at the southwestern margin of the Early Paleozoic basement of the Gemeric belt closely relates to the Early Cretaceous tectonometamorphic evo-

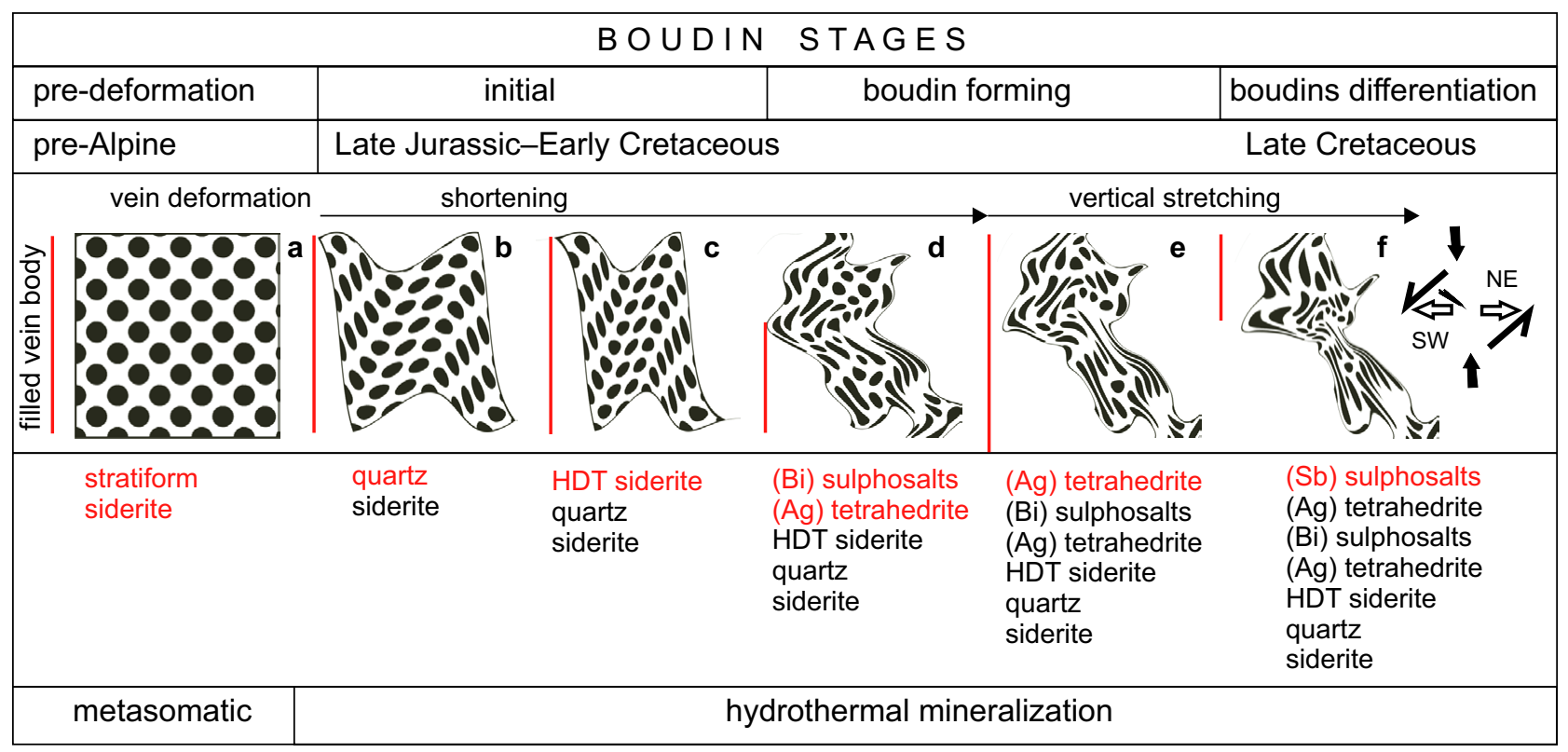

Fig. 14 Six evolutionary stages of the Strieborna vein formation reflecting interplay between mineralization and deformation processes. Mineralization phases (red colour - active) precipitated and deformed gradually either throughout the TGSZ sequential shortening or vertical stretching (Sasvári and Mat'o 1998; Mikuš et al. 2018). The vein boudinage deformations run across three successive stages. The initial stage closed precipitation of the quartz-sulphidic phase, the medial one was related to the shear deformation prior to precipitation of the first sulphosalt association. The third boudinal stage was characterized by vertical stretching of rock successions, creation of stylolites and boudins transversal necking (see Fig. 9). With depth decreasing Ag, Sb, and increasing Bi contents for sulphosalts are characteristic. The older sulphosalt association tintinaite-kobelliteBi-jamesonite-bournonite represents the older phase with the higher Bi content. In contrast, a low Bi content in tetrahedrite is a typical feature of the Gemeric belt (e.g. Pršek and Biron 2007; Števko et al. 2015). We would like to remind that both sulphosalts associations, together with Sbstibnite (see Fig. 11), as well as Čučma Sb-stibnite deposit (Beňka and Caňo 1992), terminated the veins hydrothermal mineralization in the area. 
lution of the Western Carpathians. The main results on the studied Strieborna vein formation can be summarized as follows:

1. The subduction of the oceanic crust in the Meliata oceanic trough at 152-172 $\mathrm{Ma}$ released $\mathrm{Mg}, \mathrm{Fe}$ and similar elements for their syntectonic Early Cretaceous precipitation at penetratingly prepared ore-bearing structures of the Paleozoic Gemeric belt.

2. The Strieborna vein is best developed in rheologically competent metavolcanic and metapsammitic rocks. In the less competent phyllitic media, the vein strike and thickness change, often being reduced substantially. For an initial emplacement, the vein body utilized fan-like cleavage and faults set of the Early Cretaceous regional fold axial structure, as confirm ${ }^{40} \mathrm{Ar}-{ }^{39} \mathrm{Ar}$ ages, regional metamorphic and structural data.

3. Strieborna vein deformations were markedly related to the sinistral brittle-ductile shearing along the Transgemeric shear zone (TGSZ). Five boudin bodies, several tens to more than $100 \mathrm{~m}$ in length, are observed between $6^{\text {th }}$ and $10^{\text {th }}$ mining levels of the vein. They were created at two regional dislocation sets of NNE-SSW and NE-SW directions. Both of them spatially corresponded with the principal Alpine structures of the Rožňava mining area and show slightly to moderately inclined strike-slip kinematics.

4. Boudins of specimen dimensions provide valuable information about the successive evolution of shear zone deformation, kinematics, and internal geometry as well as the precipitation of individual vein associations.

5. The oldest demonstrable Strieborna vein boudinage stage was the post-quartz-siderite one which fixed vein consecutive deformations. The presence of siderite grains rotated to the direction of stretching lineation and diagonally oriented stylolitic seams certify following successive deformations of the vein body and implicitly also the final kinematic pattern of the TGSZ.

6. Close deformation and temporal analogies are shown by the youngest sulphosalts association of the Strieborna vein and Sb-stibnite-sulphosalts of the same phase in the nearby Čučma ore vein deposit. These analogies indicate a similar genesis of terminal associations in these two vein deposits.

7. Proximal tectonometamorphic evolution of the Alpine Gemeric and South Veporic units indicates the syntectonic hydrothermal mineralization of the Rožñava ore field and also transpressional deformations of the TGSZ in Early Cretaceous (75-85 Ma ago).

Acknowledgements. We acknowledge the constructive comments and excellent editorial handling of J. Zachariáš.

\section{References}

ANDRUSOv D (1968) Grundriss der Tektonik der Nördlichen Karpaten. Slovak Academy of Sciences, Bratislava, pp $1-188$

Bajaník Š, Hanzel V, IvaničKa J, Mello J, Pristaš J, Reichwalder P, SNopko L, Vozár J, Vozárová A (1983) Explanations to geological map of the Slovenské Rudohorie Mts. - eastern part. Dionýz Štúr Geological Institute, Bratislava, pp 1-223 (in Slovak)

Bagdasaryan GP, Cambel B, Veselský J, Gukasajan $\mathrm{RCH}$ (1977) $\mathrm{K}-\mathrm{Ar}$ age determinations of the rocks from crystalline complexes of the Western Carpathians and preliminary interpretation of results. Geol Zbor Geol Carpath 28: 365-374

BaKer DEL, Seccombe PK, Collins WJ (2002) Structural history and timing of gold mineralization in the northern East Strelley Belt, Pilbara Craton, Western Australia. Econ Geol 97: 775-785

BEŇKa J, CAŇO F (1992) Mineralogy, paragenesis and geochemistry of antimony veins from the Betliar-ČučmaVolovec area. Západ Karpaty, Ser Mineral Petrogr Geochem Metalogen 15: 61-91

Bezák V, Biely A, Broska I, Bóna J, Buček S, ElečKo M, Filo I, Fordinal K, GazdačKo L', Grecula P, HrašKo L, IVANIČKa J, JaCKo $\mathrm{S}$ sen., JaCKo $\mathrm{S}$ jun., JanočKo J, Kaličiak M, Kobulský J, Kohút M, KonečnÝ V, KováčiK M, Lexa J, Madaras J, Maglay J, Mello J, Nagy Z, Németh Z, OlšavskÝ M, Plašínnka D, Polák M, Potfaj M, Pristaš J, Siman P, Šimon L, Teták F, Vozárová A, VozÁr J, Žec B (2009) Explanations to the general geological map of Slovak Republic, scale 1:500 000. Geological Survey of the Slovak Republic, Bratislava, pp 1-534 (in Slovak with English summary)

Dabrowski M, Grasemann B (2014) Domino boudinage under layer-parallel simple shear. J Struct Geol 68: 58-65

Dallmeyer RD, Neubauer F, Fritz H, Mocanu V (1994) Pre-Variscan, Variscan and Alpine tectonothermal evolution within the southern Carpathians, Romania: evidence from ${ }^{40} \mathrm{Ar}-{ }^{39} \mathrm{Ar}$ hornblende and muscovite ages. J Czech Geol Soc 39: 18-19

Dallmeyer RD, Neubauer F, Handler R, Fritz H, MülLER W, PANa D, Putrš M (1996) Tectonothermal evolution of the internal Alps and Carpathians: evidence from ${ }^{40} \mathrm{Ar}-{ }^{39} \mathrm{Ar}$ mineral and whole-rock data. Eclogae Geol Helv 89: 203-227

Dallmeyer RD, Neubauer F, Fritz H (2008) The Meliata suture in the Carpathians: regional significance and implications for the evolution of high-pressure wedges within collisional orogens. In: SIEGESMUND S, FÜGENschun B, Froitzheim N (eds) Tectonic Aspects of the Alpine-Dinaride-Carpathian System. Geological Society of London, Special Publications 298: 101-115 
FARYAD SW (1991) Metamorphism of the Early Paleozoic sedimentary rocks in the Gemericum. Miner Slov 23: 315-324

FARYAD SW (1995) Determination of P-T metamorphism conditions in the Early Paleozoic Gemericum rock sequences. Miner Slov 27: 9-19

Faryad SW, Henjes-Kunst F (1997) Petrological and K/ Ar and ${ }^{40} \mathrm{Ar} /{ }^{39} \mathrm{Ar}$ age constraints for the tectonothermal evolution of the high-pressure Meliata Unit, Western Carpathians (Slovakia). Tectonophysics 280: 141-156

Finger F, BRoska I (1999) The Gemeric S-type granites in southeastern Slovakia: Late Palaeozoic or Alpine intrusion? Evidence from the electron-microprobe dating of monazite. Schweiz mineral petrogr Mitt 79: 439-443

Ghosh SK, SENGUPTA S (1999) Boudinage and composite boudinage in superposed deformations and syntectonic migmatization. J Struct Geol 21: 97-110

Goscombe B, Passchier CW (2003) Asymmetric boudins as shear sense indicators - an assessment from field data. J Struct Geol 25: 575-589

Goscombe B, Passchier CW, Hand M (2004) Boudinage classification: end-member boudin types and modified boudin structures. J Struct Geol 26: 739-763

Grecula P, NávesŇák D, Bartalský B, GazdačKo L', NÉMETH Z, Ištván Z, VRBAToviČ P (1990) Shear zones and arc structure of Gemericum, the Western Carpathians. Miner Slov 22: 97-110

Grecula P, Abonyi A, Abonyiová M, Antaš J, Bartalský B, BARTALSKÝ J, DianišKa I, DrnzíK E, ĎuĎa R, GARGULÁK M, GAZDAČKo L', HUDÁČEK J, KOBULSKÝ J, LÖRINCZ L, Macko J, NÁvesŇÁK D, Németh Z, Novotný L, RADVANEC M, RoJKovič I, RozLožNík L, RozLožNík O, VARČEK C, ZLOCHA J (1995) Raw deposits of the Slovak ore Mountains. Geocomplex, Bratislava, pp 1-834

Grecula P, Kobulský J, BaJtoš P, GazdačKo L', HrašKo L', Kucharič L', Maglay J, Németh Z, Novotný L, Pramuka S, Radvanec M, Záhorová L' (2011) Explanation to geological map of the Spišsko-Gemerské rudohorie Mts., scale 1:50 000. Dionýz Štúr Geological Institute, Bratislava, pp 1-308 (in Slovak with English summary)

HANMER, S, PASSChIER C (1991) Shear-Sense Indicators: A Review. Geological Survey of Canada Papers 90-17, pp 1-72

Hurai V, Harčarová E, Huraiová M, Ozdín D, ProCHASKA W, WIEGEROVÁ V (2002) Origin of siderite veins in the Western Carpathians I. P-T $-\mathrm{X}-\delta^{13} \mathrm{C}-\delta^{18} \mathrm{O}$ relations in ore-forming brines of the Rudňany deposits. Ore Geol Rev 21: 67-101

Hurai V, Lexa O, Schulmann K, Montigny R, ProChaska W, Frank W, KoneČnÝ P, Král J, Thomas R, Chovan M (2008) Mobilization of ore fluids during Alpine metamorphism: evidence from hydrothermal veins in the Variscan basement of Western Carpathians, Slovakia. Geofluids 8: 181-207
JACKO S (1979) Geological cross-section through Čierna hora belt. In: MAHEL M (ed) Tectonic Cross-section of the Western Carpathians. Dionýz Štúr Geological Institute, Bratislava, pp 185-193

JACKO S, SASVÁRI T (1990) Some remarks to an emplacement mechanism of the West Carpathian Paleo-Alpine nappes. Geol Carpath 41: 179-197

KANTOR J (1957) ${ }^{40} \mathrm{Ar} /{ }^{40} \mathrm{~K}$ method for determining the absolute age and the age of the Gemeric Betliar granites. Geol Práce, Zpr 11: 188-200

Lexa J, Bačo P, Hurai V, Chovan M, Koděra P, Petro M, RoJKovič I, TrÉGER M (2007) Explanatory notes to the metallogenetic map of Slovak Republic 1:500 000 . Dionýz Štúr Geological Institute, Bratislava, pp 1-178

LeXa O, Schulmann K, JežEK J (2003) Cretaceous collision and indentation in the West Carpathians: view based on structural analysis and numerical modeling. Tectonics 22: 1066, DOI: 10.1029/2002TC001472

LloYd GE, Ferguson CC (1981) Boudinage structure some new interpretations based on elastic-plastic finiteelement simulations. J Struct Geol 3: 117-128

MAHEv M (1986) Geological Structure of the Czechoslovak Carpathians. Paleoalpine Units. Veda, Bratislava, pp 1-503 (in Slovak with English summary)

Maluski H, Rajlich P, Matte P (1993) ${ }^{40} \mathrm{Ar}-{ }^{39} \mathrm{Ar}$ dating of the Inner Carpathian Variscan basement and Alpine mylonitic overprinting. Tectonophysics 223: 313-337

Martins BD, Lobato LM, Rosiere CA, Hagemann SG, Santos JOS, Villanova FLDP, Silva RCFE, Lemos LHD (2016) The Archean BIF-hosted Lamego gold deposit, Rio das Velhas greenstone belt, Quadrilatero Ferrifero: evidence for Cambrian structural modification of an Archean orogenic gold deposit. Ore Geol Rev 72: 963-988

MesARČ́́K I (1994) Preliminary Report With Operational Reserves Calculation of the Rožňava - Silver Vein II. Unpublished manuscript, Geoenvex, s.r.o., Rožňava, pp 1-53 (in Slovak)

MesarČ́́ I, Jeleñ M, BachŇák M, Švantnerová E, Zatroch P, LeŠKa S, Hajč T, Palčo A, Tuček L, KošUth M, Ujpál Z, Marko F, Stupák J (1991) Final Report With Reserves Calculation of the Rožňava-Silver Vein. Unpublished manuscript, Geologický prieskum, š.p., Spišská Nová Ves, Geologická oblast' Rožňava, pp 1-95

MiKuŠ T, Kondela J, JACKO S, MilovsKa S (2018) Garavellite and associated sulphosalts from the Strieborna vein in the Rožňava ore field (Western Carpathians). Geol Carpath 69: 221-236

NÉMETH Z (2002) Variscan suture zone in the Gemericum: contribution to reconstruction of geodynamic evolution and metallogenetic events of Inner Western Carpathians. Slovak Geol Mag 8: 247-257

NÉMETH Z, GAZDačKo L, NÁVesŇÁK D, KobUlskÝ J (1997) Polyphase tectonic evolution of the Gemericum (the 
Western Carpathians) outlined by review of structural and deformational data. In: Grecula P, Hovorka D, PUTIŠ M (eds) Geological Evolution of the Western Carpathians. Geocomplex, Bratislava, pp 215-224

NÉMETH Z, PUTIŠ M, HRAŠKo L' (2016) The relation of metallogeny to geodynamic processes - the natural prerequisite for origin of mineral deposits of public importance (MDoPI): the case study in the Western Carpathians, Slovakia. Miner Slov 48: 119-134

Passchier CW, Druguet E (2002) Numerical modelling of asymmetric boudinage. J Struct Geol 24: 1789-1803

Passchier CW, Trouw RAJ (2005) Microtectonics. Springer, Berlin, pp 1-366

PlašIENKA D (1999) Tectochronology and Paleotectonic Model of Jurassic and Cretaceous Evolution in the Central Western Carpathians. Veda, Bratislava, pp 1-125

PlašsienKa D, Havrila M, Michalík J, Putiš M, Reháková D (1997) Nappe structure of the western part of the Central Carpathians. In: PlašIENKa D, HóK J, VozÁR J, EleČKo M (eds) Alpine Evolution of the Western Carpathians and Related Areas. International Conference, Abstracts and Introductory Articles to the excursion. Geological Survey of Slovak Republic, Dionýz Štúr Publisher, Bratislava, pp 139-161

Plašienka D, Grecula P, Putiš M, Kováč M, Hovorka D (1999) Evolution and structure of the Western Carpathians: an overview. In: Grecula P, Hovorka D, PUTIŠ M (eds) Geological Evolution of the Western Carpathians. Geocomplex, Bratislava, pp 1-24

Poller U, Uher P, Broska I, Janák M, Plašienka D (2002) First Permian-Early Triassic zircon ages for tin-bearing granites from Gemeric Unit (Western Carpathians, Slovakia): connection to the post-collisional extension of the Variscan orogen and S-type magmatism. Terra Nova 14: 41-48

PrŠEK J, BIROŇ A (2007) Jaskólskiite and associated sulphosalts from Aurélia vein, Spišsko-gemerské rudohorie Mts. Miner Slov 39: 141-146

Putiš M, Ivan P, Kohút M, Spišiak J, Siman P, Radvanec M, Uher P, Sergeev S, Larionov A, Méres S, Demko R, ONDREJKA M (2009) Meta-igneous rocks of the West-Carpathian basement, Slovakia: indicators of Early Paleozoic extension and shortening events. Bull Soc geol France 180: 461-471

RAJABZADEH MA, RASTI S (2017) Investigation on mineralogy, geochemistry and fluid inclusions of the Goushti hydrothermal magnetite deposit, Fars Province, SW Iran: a comparison with IOCGs. Ore Geol Rev 82: 93-107

Ramsay JG, Huber MI (1987) The Techniques of Modern Structural Geology. Volume 2: Folds and Fractures. Academic Press, London, pp 516-633

ReICHWALDER P (1982) Structural characteristics of root zone of some nappes in innermost parts of West Car- pathians. In: MAHEL M (ed) Alpine Structural Elements. Carpathian-Balkan-Caucasus-Pamir Orogene Zone. Veda, Bratislava, pp 43-56

RoACHE TJ (2004) Shear zone versus fold geometries at the Cannington $\mathrm{Ag}-\mathrm{Pb}-\mathrm{Zn}$ deposit: implications for the genesis of BHT deposits. J Struct Geol 26: 1215-1230

Rodrigues B, Pamplona J (2018) Boudinage and shearband boudins: a meso- to micro-scale tool in structural analysis. J Struct Geol 114: 280-287

Rodrigues BC, Peternell M, Moura A, Schwindinger M, Pamplona J (2016) P-T path development derived from shearband boudin microstructure. J Struct Geol 90: $95-110$

RozLOŽNíK L (1976) Relationship of Siderite Metalogenesis and Tectonics of the Spis Ore Mountains and Their Position in Alpides. Faculty BERG, Košice, pp 1-301

RozLožNík L (1980) Classification of the mineralized structures in the Spišsko-gemerské Rudohorie Mts. Geol Carpath 31: 421-439

RozLožNík L (1984) Source and structural conditions of siderite deposits formation in the Spišsko-gemerské Rudohorie Mts. (West Carpathians). Proceedings of the Sixth IAGOD Symposium. Schweizerbart'sche E. Verlagsbuchhandlung, Stuttgart, pp 187-189

RozLožNík L (1990) Gemericum shear zone - bearer of siderite formation. Miner Slov 22: 47-54

Samanta SK, Majumder DB, Sarkar G (2017) Geometry of torn boudin - an indicator of relative viscosity. J Struct Geol 104: 21-30

SASVÁri T, MAŤO L' (1998) The characteristics of the Rožňava ore district, in relation to the structural-tectonic analysis and mineralization exampled by the deposition conditions of the Strieborna vein, Mária mine, Rožňava. Acta Mont Slov 3: 33-117

Schulmann K, Kröner A, Hegner E, Wendt I, KoNOPÁSEK J, LEXA O, ŠTÍPSKÁ P (2005) Chronological constraints on the pre-orogenic history, burial and exhumation of deep-seated rocks along the eastern margin of the Variscan Orogen, Bohemian Massif, Czech Republic. Amer J Sci 305: 407-448

Smith MT, Rhys D, Ross K, Lee C, Gray JN (2013) The long canyon deposit: anatomy of a new off-trend sedimentary rock-hosted gold discovery in northeastern Nevada. Econ Geol 108: 1119-1145

Števko M, Sejkora J, Peterec D (2015) Grumiplucite from the Rudňany deposit, Slovakia: a second worldoccurrence and new data. J Geosci 60: 269-281

VARČEK C (1963) Hydrotherm mineralization zonality of the Spiš-Gemer Ore Mountains and geological structure impact to mineralization pattern. In: X Congress of Carpathian-Balkan Geological Association, Bucharest 1961, Guide to Excursion, pp 277-292

VARČEK C (1973) Paragenetic and geochemical patterns of hydrothermal deposits in the Spiš-Gemer Ore Moun- 
tains. In: BARTALSKÝ J (ed) Geological Ore Study of the Spiš-Gemer Ore Mountains. Komenského University Publisher, Bratislava, pp 1-122 (in Slovak)

VozÁroví A (1993) Variscan metamorphism and crustal evolution of the Gemericum. Západ Karpaty Sér Mineral Petrogr Geochem Metalogen 16: 55-117 (in Slovak with English summary)
VozÁrová A, IvaničKa J (1996) Geodynamic position of acid volcanism of the Gelnica Group (Early Paleozoic, southern Gemericum; Inner Western Carpathians). Slovak Geol Mag 3-4: 245-250

VozÁrová A, Rodionov N, VozÁr J, LePeKhina E, ŠARINOVÁ K (2016) U-Pb zircon ages from Permian volcanic rocks and tonalite of the Northern Veporicum (Western Carpathians). J Geosci 63: 221-237 